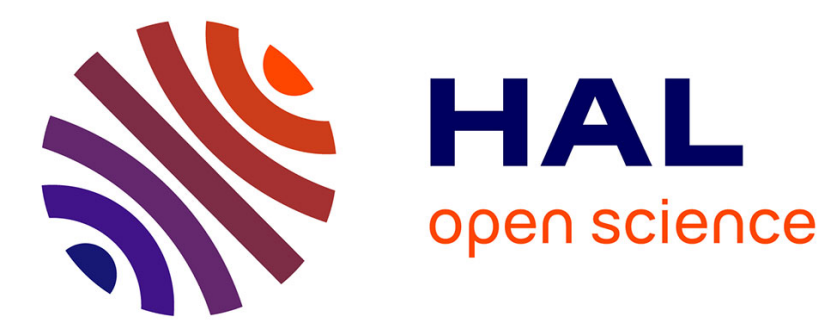

\title{
Immobilization of a Neutral Protease in Magnetic Particles Using Direct Binding Procedure
}

\author{
M. Koneracká, C. Ramchand, R. Mehta, P. Kopcanský
}

\section{To cite this version:}

M. Koneracká, C. Ramchand, R. Mehta, P. Kopcanský. Immobilization of a Neutral Protease in Magnetic Particles Using Direct Binding Procedure. Journal de Physique IV Proceedings, 1997, 07 (C1), pp.C1-671-C1-672. 10.1051/jp4:19971274 . jpa-00254986

\section{HAL Id: jpa-00254986 https://hal.science/jpa-00254986}

Submitted on 1 Jan 1997

HAL is a multi-disciplinary open access archive for the deposit and dissemination of scientific research documents, whether they are published or not. The documents may come from teaching and research institutions in France or abroad, or from public or private research centers.
L'archive ouverte pluridisciplinaire HAL, est destinée au dépôt et à la diffusion de documents scientifiques de niveau recherche, publiés ou non, émanant des établissements d'enseignement et de recherche français ou étrangers, des laboratoires publics ou privés. 


\title{
Immobilization of a Neutral Protease in Magnetic Particles Using Direct Binding Procedure
}

\author{
M. Koneracká, C.N. Ramchand*, R.V. Mehta** and P. Kopcanský \\ Institute of Experimental Physics of the Slovak Academy of Sciences, Watsonova 47, 04353 Kosice, \\ Slovakia \\ * Department of Biomedical Sciences, University of Sheffield, Sheffield, U.K. \\ ** Department of Physics, University of Bhavnagar, Bhavnagar, India
}

\begin{abstract}
In a recent study we have found that Bovine serum albumine (BSA) can be bound to freshly precipitated magnetic particles directly by a novel procedure. In this procedure BSA linked covalently to the -OH group of $\mathrm{Fe}_{3} \mathrm{O}_{4}$ using Carbodiimide. The binding was confirmed by FTIR spectra and electron microscopy. We have also immobilized several enzymes which have biomedical application using this procedure and confirmed the binding by the above mentioned method. In the present experiment we have immobilized Dispase, a neutral protease using the direct binding procedure. We have found that the protein was bound to the extend of $90 \%$ using the dye binding procedure. We have measured the activity of this enzyme by its proteolytic property and showed that it retained $80 \%$ of its activity after immobilization.
\end{abstract}

\section{Introduction}

During the past decade it was demonstrated that magnetic particles coated with a suitable stabilizer can not only serve as an efficient and advantageous diagnostic agent in the field of medicine but are also useful in the field of biotechnology. For example Lauva et al [1] used heparin - stabilized colloidal magnetite for binding cells from whole blood, dextran - coated magnetite was used by Rusetski and Ruuge as a drug carrier [2] while Witherspoon et al [3] used silane - coated ferrite particles for radioimmuno assay.

The aim of this work was to show the possibility of immobilization of dispase (neutral protease) to freshly precipitated magnetic particles directly by covalent binding in the presence of carbodiimide. This method of binding can also be adopted for cells, antibodies, enzymes and proteins.

\section{Materials and experimental methods}

The magnetic paricles $\mathrm{Fe}_{3} \mathrm{O}_{4}$ used in the experiment were made by addition of an ammonium hydroxide solution to a solution containing 2 moles of ferric $\left(\mathrm{FeCl}_{3} .6 \mathrm{H}_{2} \mathrm{O}\right)$ and 1 mole of ferrous $\left(\mathrm{FeSO}_{4} .7 \mathrm{H}_{2} \mathrm{O}\right)$ salts. Then impurity ions such as chlorides and sulphates were removed by washing several times with distilled water. The average particle size diameter was determined from observation under electron microscopy (Fig.1a) and was found to be $10 \mathrm{~nm}$.

The reagents used for the immobilization such as dispase (neutral protease), carbodiimide and brilliant blue G dye (for estimation of the proteins from unreacted fraction) were obtained from the SIGMA chemical company. Stock solution of dispase in phosphate buffer $(\mathrm{pH}=6.3)$ and carbodiimide were stored at $4^{\circ} \mathrm{C}$. The reaction mixture contained dispase, magnetic particles and carbodiimide in phosphate buffer in the ratio of 1:2:2. It was shaken for a period of $24 \mathrm{hrs}$ at room temperature. After $24 \mathrm{hrs}$ samples were placed on the top of a bar magnet where sedimentation of magnetic particles occured within 2 minutes. The reacted as well as unreacted fraction of proteins were examined by two independent methods, e.g. by FTIR and by dye binding method. The magnetically sedimented fraction was washed and decanted several times with distilled water and acetone. In order to assess the binding of magnetic particles to protein FTIR was used (Fig.2b). The percentage of bound proteins was estimated by determining the amount of protein in unreacted fraction using dye binding procedure. 


\section{Results and discussion}

By comparing figures (Fig.1 a, Fig. 1b) for reacted fraction of magnetic particles from electron microscope one can see that there exists a layer on the surface of the particles which shows the coating of protein molecules on the particles.

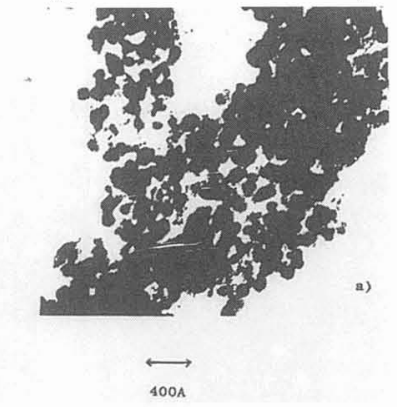

Figure 1a: Electron micrograph of magnetic particles

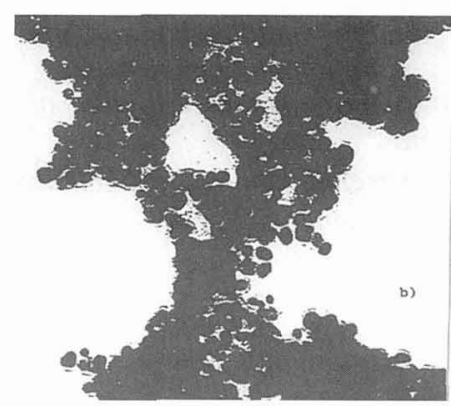

Figure 1b: Electron micrograph of protein bound magnetic particles

This was also confirmed by FTIR spectra of the protein (Fig.2a) and of the reacted fraction of particles (Fig.2b). The characteristic bands of protein at $1648 \mathrm{~cm}^{-1}$ and $1540 \mathrm{~cm}^{-1}$ were also observed in the reacted fraction of the particles.

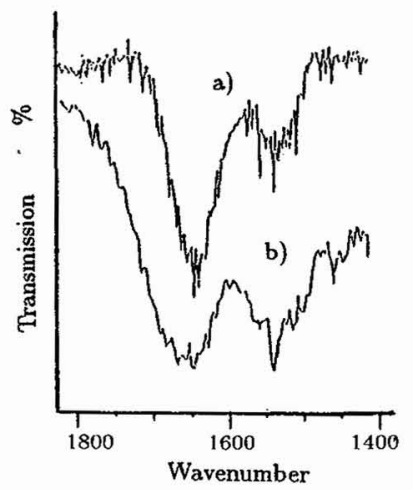

Figure 2: FTIR Spectrum of (a) protein and (b) protein bound magnetic particles

Results obtained from dye binding procedure showed that more than $90 \%$ of added dispase was bound to magnetic particles. Activity of this dispase was also measured and it was found more than $80 \%$ of the added activity of dispase was retained.

The abtained results clearly show that it is possible to bind proteins on magnetic particles in the presence of carbodiimide without the aid of primary coating. Binding is due to the presence of hydroxyl groups on the surface of freshly prepared magnetite. The usefulness of the present method is mainly in biomedical applications especially in enzyme targeting in different diseases and applications in biotechnology field in drug targeting such as targeting streptokinnase to solubilize blood clots in coronary arterial diseases [4].

\section{Acknowledgment}

This work was supported by the British Council and Slovak Academy of Sciences within the framework of Project GAV No. 1361.

\section{References}

[1] Lauva M., Auzans.E, Levickis V. and Plavins J., J. Magn. Magn. Mater. 85 (1990) $295-298$.

[2] Rusetski A.N. and Ruuge E.K., J. Magn. Magn. Mater. 85 (1990) 299 - 302.

[3] Witherspoon L.R., Shuler S.E. and (xilbert. S.S., Clin. Chem. 31 (1985) $415-419$.

[4] Ramchand C.N., Clark A.E., Charles S.W., Wells S., Upadhyay R.V., Bhatnagar S. and Mehta R.V., Biornedical applications of magnetic fluids in vascular occlusive diseases and cancer chemotherapy for targeting specific drugs. Application of direct binding method, 7 th ICMF Conference, Bhavnagar, India, 9-14 Jan. 1995,281 282. 